potentially disastrous diminution of human resources.

J. D. Y. Peel, in 'Perspectives on nationalism in black Africa', addresses the thorny issue of nationalism and its relationship to the African 'state' (especially Nigeria), concluding that the colonial bequest was, and is, incapable of embracing and reconciling the many and protean nationalisms within a wider ('bourgeois') elite) nationalism which precipitated independence. The contemporary 'African state' is, according to Peel, 'least grounded in the consciousness general population'

A CALLAN

School of Oriental and African Studies,

London

CHERRY GERTZEL, Uganda: an annotated bibliography of source materials (with particular reference to the period since 1971 and $u p$ to 1988). London: Hans Zell, 1991, 238.

7 ANNE THURSTON, Guide to Archives and Manuscripts relating to Kenya and Eas Africa in the United Kingdom. London: Hans Zell, 2 vols. $1991,1,213$ pp. in

$£ 120$ the pair, ISBN 9905450477 .

Here are three valuable guides to research materials on East Africa. Cherry Gertzel' volume is described on the back cover as comprehensive partially annotated bibliog raphy intended as a guide to the materials available for the study of Uganda's recent history and politics, with particular reference to the years since the Amin coup in 1971 . Yer, on the decision, in 'the absence of any comprehensive bibliography of secondary sources for the years since independence in $1962 \ldots$ to include both those earlier materials as well as more recent secondary works that I have myself consulted'. No harm in that. In fact quite a lot of valuable materials for the period before 1962 is included which will also be of great interest to researchers into Uganda. The basic problem is that for the years 1971-88 the volume is not fully comprehensive. Sometimes even items on Uganda in books or volumes which D Gertzel cites for other material of interes to her on Uganda are omitted. The volume cannot therefore be regarded, as the publisher claims on the rear cover, as 'comprehensive'. However, it should prove useful for researchers just starting to do work on Uganda, who will be able to fill in the gaps in it as their own researches progress. Anne Thurston's two volumes are very different. Arising out of work undertaken for the Kenya government, they provide very full guide to archival materials in Britain concerned with Kenya. The first volume lists files in official repositories almost file-by-file in the case of the Public Record Office up to the 1950s. The second volume lists 'Non-official archives and manuscripts' in the UK, and this time the comment on the back cover that Because the pattern of documentation tends to be similar for other Commonwealth countries, particularly in Africa, the guide will also give researchers interested in these areas a good indication of where relevant material is likely to be found' may be taken as fair comment. Its practical value is further enhanced by each archival collection listed being given a telephone number. MICHAEL TWADDLF Institute of Commonwealth Studies,

\section{YOUNG PURITAN PREACHERS IN \\ POST-INDEPENDENCE MALAWI}

Richard A. van Dijk

During the early 1970s Malawi witnessed the rise of a new religious phenomenon in its largest city, Blantyre. ${ }^{1}$ Young people began to attract crowds by conducting revival meetings in markets, bus stations and other public places. They zealously promulgated a Christian fundamentalist doctrine which rejected several aspects of everyday life in urban Malawian society. The fire-and-brimstone preaching offered clear-cut definitions of the evils of life: adultery, promiscuity, violence and the consumption of alcohol, cigarettes and drugs were strongly denounced. In addition, the young preachers demanded not just a renewed moral strictness but required listeners to show their repentance then and there by kneeling down in front of everyone; they insisted on the handing in of stolen goods, tobacco, knives and any magical amulets. Spectators were urged to step forward, at the "call to the altar', and receive the 'inflowing' of the Holy Spirit through the blessings given by the young preachers. Those who came forward were considered to have been kubadwa mwatsopano, 'born again'; hence the revival led by young religious enthusiasts and to be found in various parts of Blantyre came to be known simply as the Born Again movement.

The religious zeal has continued to the present day, and young people can still be found in Blantyre preaching a Born Again ideology (van Dijk, $1990 \mathrm{a}, \mathrm{b}$ ). These young itinerant preachers (alaliki, sing. mlaliki) proclaim that, for anyone who has once experienced being Born Again, the forces of darkness, evil spirits and even witchcraft have lost their sway over life; to be Born Again is to be cleansed. Hence their ideology involves a strong sense of a puritanical battle being fought against omnipresent evil, a campaign to render ineffective the ambushes set by various malicious forces. Very significantly, this ideology is not tailored to a single, specific religious denomination; the call to be Born Again stresses the purification of a person's life as an individual, irrespective of any affiliation. The Born Again movement should therefore be regarded not as a kind of corporate group, but rather as a movement that fosters and promotes a specific religious identity, and takes on quite different organisational forms.

The movement and its ideology have a strong urban bias. The topics the young preachers touch upon in their sermons, their style of dress and their socio-economic background reveal not only deep involvement in urban life but also firm rejection of village culture. Although occasionally young preachers embark on campaigns to take their message to the countryside in so-called 'crusades', by and large the Born Again ideology is most successful in propagating puritan and fundamentalist views within an urban environment. The Born Again preachers have found that the city-with its markets, schools, factories and other key public places-provides the most rewarding sites for spreading their message.

The preference for the urban environment is significant. As Thoden van Velzen and van Beek have shown in their world-wide review of 
puritan movements, a common, unifying force in the eradication of defilement and evil from society is the urge to create "islands of righteousness in a sea of iniquity', thus bringing into being 'small pockets of the faithful' in which there 'can be such a community-orientedness that the true puritan may stay clean despite a foul environment (Thoden van Velzen and van Beek, 1988: 10). Puritan movements generally may thus be seen to demand control over space to such an extent that their quest for a purified community may in fact lead them to withdrawal from the wider world and ultimately to sectarian isolation. In particular, this process seems to occur in movements found in urban areas. In a number of studies of religious groupings and independent Churches in urban areas in the southern African region, this puritan tendency to set up isolated pockets of believers has been well recognised. ${ }^{2}$ Of particular interest are the studies on exclusive Zionist groupings by West (1975), Kiernan (1974, 1976, 1977 1982) and Comaroff (1985), who all focus on the issue of how these Zionist groups cope with modern, urban and sometimes oppressive conditions through, among other things, the creation of puritan communities. These units maintain clear boundaries and by means of various techniques, symbols and rituals try to withdraw from the threatening world beyond and to seek means of preserving the small, close-knit family units identified as 'traditional'. 'This 'exclusiveness', as Kiernan has called it, strengthens the image of communalism that appeals strongly to the rural migrant lost in the bewildering alienation of city life (cf. Werbner, 1985).

This article aims at exploring the question of why the Born Again movement as a whole, though undoubtedly puritan, does not seem to go in for forming such exclusive pockets of faith. Neither in Born Again ideology nor in the way meetings are conducted is any play made with symbols or rituals that would sharply divide insider from outsider. Instead, I argue, the young Born Again preachers try deliberately to create for themselves a certain moral space by going along with modern socio-political styles, styles that require that ideas be preached in a tactful, urbane manner. The space thus created is not empty, but permits an assertive empowerment of the individual. Such power is attractive to those, born and raised in towns, who maintain only minimal ties with the villages from which their families once came. As a consequence the Born Again ideology has little to offer the 'lost' rural-urban migrant, since no traditional communalism is being regenerated. Nor does it contain any specific meaning for those who are signally failing to cope with modern urban conditions, since the emphasis is upon assertiveness, success in life and entrepreneurship. In short, the Born Again preachers have occupied the middle ground that lies between, on the one hand, a fierce rejection of village life and, on the other, strong denunciations of certain aspects of urban life. This simultaneous rejection of aspects of both traditional and modern culture means, above all, taking a stand against the (allegedly magical) techniques that the elders are supposed to use to ensure their own power and success in life. Taking advantage of their new moral space, preachers firmly repudiate any ambiguity over the use of such techniques, whether for benign or for malicious purposes.
URBAN PURITANISM AND ITS COMPLEXITY: THE CASE OF THE BORN AGAIN

One Sunday in December 1988 a crowd of people could be seen flocking to a small mud-brick building at the west end of Mbayani township, a poverty-stricken, congested squatter settlement in Blantyre. There a voice could be heard shouting, all the time as if in the utmost anger, and evoking from the gathering a certain sense of distress. At an extraordinary speed the voice could be heard yelling questions like 'Are you saved? Ladies, are you saved? Did your grandparents teach you how to dance at night naked, how to do your evil tricks in the graveyard? Beware! When Jesus comes, there will be weeping, crying, running away! Are you saved?' And some in the audience would sob in response to each call; a great sorrow seemed to come over the gathering.

Once inside the church, it was clear that this shouting was not coming from one of the fifteen Church elders present, nor did it emanate from the tall figure in long black robes who proved to be the bishop-leader of the branch of the African International Church to which this particular congregation belonged. On the contrary, it was a young woman, about twenty years of age, dressed in a white robe, who was yelling and screaming at the top of her lungs, stamping her feet, jumping up and down as if in agony; to emphasise her words, she flayed the air with clenched fists. It was an extraordinary display of violence- of verbal violence.

But worse was to come for the gathering. Without prior notice the girl started to point at individuals among her audience, explaining that she could see a hand coming down from heaven and indicating to her the sinners on earth. A number of people, who turned out to be her assistants, picked out from the audience those she pointed at, and took them up front. There, laying her hands upon them, she urged them to repent and to empty their pockets. To demonstrate how she had indeed picked out the sinners from the audience, she straight away threw what was handed to her down on a table, in full public view. There were packets of tobacco, a knife and a few magical amulets (zitumwa) - all to be confiscated. As this was going on, the bishop was frowning and looking displeased. With a final prayer the young woman dismissed the sinners and sent them back to their places. In some haste, and without any order, the meeting broke up. The items confiscated were thrown in the pit latrine just behind the church.

The following Sunday, in Blantyre's smart business centre, a crowd of two or three hundred well dressed young people gathered at a hall; it soon proved too small to hold everybody. While waiting for the main part of the meeting to start, rousing songs were sung, and these created a lively, excited atmosphere. These songs then turned into a prayer started by two or three at the front of the gathering, to which everybody immediately responded. Gradually the volume of sound grew until the combined voices of nearly three hundred people shouting their prayers reached a deafening crescendo. Here and there, stretched-out hands began to tremble, bodies began to shiver and shake, faces started to sweat profusely. The ecstasy reached a peak, then slowly the loudness lessened and voices were lowered until here and there only some whispering and sobbing were to be heard. 
At this point an energetic young man stepped forward from behind a table placed near the lectern. Seated behind the table and facing the audience was a group of about twenty young men; they were all dressed in executive-style suits, with briefcases at their feet. The young man, also in an immaculate three-piece suit, addressed his audience with fervour and a quite formidable voice, shouting 'Halleluja! Halleluja!' The audience reacted with cheers and laughter, calling, 'Let's clap hands for Jesus!' and hundreds of clapping hands and stamping feet thundered out, drowning all other sounds. In perfect English, but with a Chichewa interpreter at his side, the young man delivered a fire-and-brimstone sermon. There was no misunderstanding his message. 'Have you repented of your sins? Sin creeps into your heart as rats into the nkhokwe [granary]. Beware! Repent before it is too late!' A call to the altar followed, so that those with personal problems who wanted to repent and be prayed for could step forward. About seventy persons did so, and those seated behind the table now came to assist in the laying on of hands and in calling out a prayer at the top of their voices-'In Jesus' name, Devil, go out from this person!' There was no asking what was the actual problem or the reason for stepping forward.

As the meeting closed the young preacher was surrounded by other young people. He had to shake a lot of hands, he arranged appointments and dealt with other matters; he also prayed individually with those who specifically asked for this. Then it was time for him to go. While others walked away or drove off, he jumped into his immaculate light-blue Toyota Space Wagon and waved goodbye.

These two examples of the way Born Again preachers work today indicate something of the kaleidoscopic variety of organisational forms and meeting styles which have come into fashion over the past two decades. Within the Born Again movement as a whole, fixed institutionalised forms and organisational structures play only a minor part; the emphasis instead is more on flexibility. Full denominational membership is a rarity. The most frequent organisational form used by young preachers is the one described in the first example above, and is usually called a 'ministry'; less common is the 'church' described in the second example. The difference between the two is that the first preacher and her Redemption Voice Ministry do not cater for a fixed membership with fixed dates, places and times to meet, nor does she provide for 'ordained' functions such as funerals, weddings, baptisms; but the second by and large does, being one of the more institutionalised Born Again organisations. The first preacher had on this particular occasion been invited by the African International Church to preach the Born Again message at one of its services; she came therefore neither as a leader nor as a member of that Church, the congregation were not in any sense part of her following, nor were there any other institutional ties of any kind between the two. The young preacher in the second example, by contrast, was dealing with a following which most certainly was his, and his alone; the congregation were organised and led by him and he remained in charge throughout the entire meeting. Yet what both preachers had in common was the zeal with which they made the proclamation of the Born Again ideology the centrepiece of their mission.

Apart from such 'ministries' and the occasional 'church', there is a third form in which young preachers seem to be especially active: the 'fellowship'. Fellowships are mainly found operating in particular residential areas, the so-called townships. Usually the fellowship functions as a localised ministry, that is to say, it organises meetings without catering for a fixed membership, but the site of its meetings is always a specific township. It therefore makes for a rather closer, face-to-face relationship between the preacher and other Born Again believers.

In each type of organisation run by the young preachers (church, ministry, fellowship), meetings for worship can take many forms. Apart from openair assemblies, mentioned above, there are lunch-hour meetings, there are nights of prayer that last from dusk to dawn, there are prayer sessions which take place up on one of the four hills that surround Blantyre; there are house-church meetings and, of course, especially for Churches there are Sunday morning services. For instance, the preacher from the Living Water Church (our second example) could be found conducting services on Sunday morning while during the following week he might attend nights of prayer or house-church meetings at several different places around Blantyre. Similarly the young woman preacher of our first example could find herself invited anywhere to address a gathering, but she might also organise meetings herself. Significantly, it was usual for preacher-leaders to open a meeting with a reference to the specific church, ministry or other grouping to which he or she belonged.

Currently operating in Blantyre are about fifteen organisations headed by young preachers, and in some cases they 'employ' other, often even younger, preachers to assist in conducting the full range of meetings. In all, there are about thirty to forty young people, aged between fifteen and thirty years old, who are active either part-time or full-time in these various Born Again organisations and who are to be found at the various meetings. The preachers and various organisations are linked in several ways. As a general rule, Born Agains as well as preachers tend to move from one organisation to another and from meeting to meeting without reference to possible doctrinal differences. There is a strong sense of close co-operation and mutual support in the conduct of preaching sessions, and this further encourages followers to plan visits to various organisations and attend meetings throughout the week. This lends support to the notion that the Born Again movement should be viewed as a religious network, access to which is open to all who have been at some time 'born again'.

The young preachers who are active in these organisations and at the meetings have a number of characteristics in common. Firstly, most have been either born or raised in town and have seen village life only at a distance, or their experience of villages has come mainly through occasional visits. Their ties with a formally recognised 'home-village' (kumudzi) are kept to a minimum. Secondly, the preachers have usually been brought up in neolocal, nuclear households where the household head settled in Blantyre many years earlier, initially for reasons of education and employment. In their turn, if and when the young preachers marry, they too establish a neolocal, nuclear family which the bourgeois Born Again ideology both promotes and is promoted by. Furthermore, the young preacher population (and, as far as I have been able to establish, the population of 
confirmed Born Again believers too) reflects the multi-ethnic composition of Blantyre society generally; in the Born Again organistions tribal background does not seem to have any significance at all.

All young preachers-and this is quite unusual when seen in the context of other evangelical groups in Malawi-prefer to operate independently of any established main-line or mission Church whatsoever. Without exception the young preachers tend to be rather critical of the moral lukewarmness of the major Presbyterian, Catholic, Seventh Day Adventist or similar important Churches (van Dijk, 1990b). Overall, the young preachers seem to have been influenced mainly by the introduction into Malawian society of a specific type of evangelical and pentecostal movement which has its roots in developments abroad, in the same way as the charismatic revival of the early 1970s arose in Nigeria (Ojo, 1988; see also van Dijk, 1990a). Both for Malawi and for Nigeria specific mention needs to be made of the influence which certain American and South African pentecostal notions have had on the fundamentalist ideology of the Born Again message (for Nigeria see Ojo, 1988: 175). The last but certainly not least important attribute shared by all preachers is that, irrespective of the exact year they began preaching, all started their religious activities when they were no older than their late teens-the youngest preacher I have met so far was only nine years old.

Nonetheless as a group young preachers can be subdivided according to age and socio-economic status. The preacher population falls into two halves, one older, the other younger-the older being about thirty years of age, the younger around twenty to twenty-five. The older cohort of preachers in fact forms the hard core of the entire young preacher phenomenon. They have been the ones who in the 1970 s started the practice of preaching independently of the established, main-line Churches in Blantyre. They are regarded as the pioneers, the ones who triggered their age-mates and younger people into revivalistic activities; it is they who first catered for a wider interdenominational audience and attracted a nonsectarian attendance. They are also the ones who were first to start the younger preacher organisations which in some cases have now turned into formal Churches; they have also inspired a second generation to follow in their footsteps and to become inspired preachers themselves or at least to join an existing preachers' group. The preacher in our second example is one of this group: he started preaching at the age of nineteen in the late 1970 s and soon attracted younger preachers in their late teens; they are now preaching the Born Again ideology in many parts of Blantyre and proclaim their Church. By contrast, our first example is one of the younger band of preachers: she began preaching only in the mid 1980s at a time when other Born Again preachers were already well known in the town.

The two groups of preachers are divided by a second factor-their socio-economic position in life. The older preachers are manly men (more rarely women) who are generally better educated, having obtained at least a few years of secondary schooling, though some have completed university or college education. Their qualifications have enabled them to hold positions of some status within society and in some cases they have combined careers in a formal job with a career in preaching. Furthermore they have been able, mainly through their privileged education, to benefit from the economic development boom which Blantyre experienced during the early 1970 s and ' 80 s. $^{3}$ By contrast, the younger cohort of preachers have generally had only a few years of primary schooling at the most; some have tried to gain access to secondary schooling but failed their exams or could not acquire the necessary financial support. In consequence, the older cohort of preachers are well established, living in good houses with piped water, electricity and a telephone; some can even afford to run a car. Such a successful social and religious career has so far proved beyond the reach of the younger preachers.

Among the kinds of jobs that the older preachers hold are those of bank manager, lawyer, accountant, etc., jobs which permit them to work parttime in preaching or in leading a ministry. Whenever they have resigned from such a job in order to devote themselves to work as full-time preachers, they have made sure they have sufficient financial backing; it may have been partly generated through international contacts and travel. They have become religious entrepreneurs, the best example being perhaps the young preacher Willie Chaponda, of the Living Water Church, who runs a clothing boutique called Kingdom Creations. On the first floor of his shop he has a large room where every lunchtime prayer meetings are held, thus giving rise to a profitable business combining marketing with evangelisation. In many ways the ambitions of the younger generation are fed by a desire for a similar religious and social career.

If we now turn our attention to the content of the message of Born Again meetings we will find that at its centre is the experience of 'infilling' by the Holy Spirit. This is seen as a process of personal empowerment, and success in life is dependent on the way this empowerment is maintained and enhanced. 'Infilling' by the Holy Spirit is viewed as an alternative road to becoming kukhwima, of reaching successful maturity in life.

RIGIDITY AND THE MORAL ORDER

At every Born Again meeting the process of personal, individual empowerment requires entry into a trance-like state. Submitting oneself in such a state to what is called 'infilling' by the Holy Spirit (which manifests itself through speaking in tongues) is the key here. In many electrifying meetings 'infilling' is displayed with great energy and force: people roll upon the ground, sweat profusely and shout, making all kinds of incomprehensible sounds. This phase is called malilime, literally 'tongues', and is mandatory in the sense that in order to become a confirmed Born Again it is necessary to experience malilime, thus enhancing not only one's own status as Born Again but also the spiritual status of the group as a whole. Mallime shows that one has succeeded in tapping into a superior power which at the same time has a purifying, healing and protective quality. By becoming Born Again one has established a direct line to heavenly powers which are thought to enable an individual to overcome the evil forces both of the 'world' and of Satan. It is the absolute assurance that the line to these benevolent powers is open and without distortion which in its turn makes it possible to withstand witchcraft and be healed of its afflictions, to cast out 
evil spirits and even to withdraw from traditional religious obligations without having to fear the consequences. Any breach by the Born Again of their puritan principles, however, automatically endangers this bond with the heavenly powers; it impedes the effectiveness of malilime and obstructs both the outpouring of power and the 'infilling' with the Holy Spirit. In social life therefore, to abstain from drinking, smoking, running around with the girls is considered the sine qua non for maintaining and enhancing not only the status of being Born Again but also the personal empowerment and protection that it offers.

The argument can be taken further: there is specifically the notion that malilime is enhanced by staying away both from witchcraft on the one hand and from the 'worldliness' of politics on the other. Witchcraft, associated as it is with the 'village', and with politics (in its intimate involvement in the realities of urban life), are seen by the young preachers as the two key resources used by the elderly to reach a state of being kukwhima, the stage in life when one is 'hardened' and 'ripe'. The young preachers propose instead to attain that state of being kukhwima by going through malilime -in short, they offer an alternative route to empowerment.

Kukhwima has primarily the connotation of being capable of controlling the forces of witchcraft and sorcery and as a consequence applying them for one's own ends. Therefore, in this section, we will first of all concentrate on the young preachers' rejection of empowerment through witchcraft and sorcery. They rigidly reject any involvement in witchcraft, and especially the use of amulets and other items which are meant to reinforce a person in everyday life, in his or her economic, social and sexual affairs. Some young preachers use direct actions and destroy these witchcraft-laden objects, in an iconoclastic attempt to purge society of evil. They allow no negotiation, no middle ground for a compromise. In this respect the bestknown case is the young woman preacher mentioned above, who claims to have died and then been raised from the grave to carry out a God-given assignment 'to warn the people of His wrath'. During her preaching sessions she gives her audience her message with great aggressiveness: quite bluntly she calls her audience a bunch of drunkards more interested in nocturnal orgies where witches (afliti) eat human flesh and dance naked $(k u t a m b a)$ than in singing loudly and enthusiastically for God. She lashes the audience with insult after insult, exploding in anger and in agony thus:

You fools, you sing as if you have eaten nothing: you have caten porridge while doing several [evil] things, but if we had been dancing at night naked [kutamba] you would have been doing it with power! [L.M., African International Church, Mbayani township, 18 Decemeber 1988]

She continuously humiliates her audience with all sorts of accusations not just of drunkenness but also of adultery, but above all of being involved in witchcraft and sorcery, of being nthakati, experts in sin and malice harming others and eager to disrupt society. She makes it perfectly and firmly clear to her audience that she knows how to deal with their involvement in Evil, with their use of magical objects, charms and amulets, and she points a finger at the disrupting influence of the elderly and the dead.

Where do you think you shall go with those charms which were left to you by your grandparents [agogo]? You fools! You, you are learners today. It takes hours for you to bewitch a person, but still you cling to your $u$ fit $i$, just because your forefathers handed over the charms to you. Fools! If these charms were things which could lead somebody into the Heavenly Kingdom, I doubt that you which could lead sover grandparats would have handed them over to you. But because charms are things that lead a person to hell-that's why they handed them over to you before they died! Just to increase the number of people joining them on their way to hell! [L.M., at Jama Open Air Ground, Mpemba, 8 March 1989]

The preacher here is very keen to confiscate the charms and amulets which are commonly referred to as zitumwa (sing. chitumwa). In her view (and it is a view generally shared by all young preachers), a chitumwa can have been obtained only in order either to gain success in life or to do harm to rivals and others. An amulet may make a business run smoothly, it may win you wealth or prestige, or success in sexual liaisons, and so on: in short, it is geared towards 'worldly lusts and temptations'-all the things money can buy. Zitumwa are thought to have explicit strategic value and therefore should be carried close to the body and invisible to anyone else; it would be foolish to let rivals know you have this magical weapon in the battle for economic gain and social prestige. Zitumwa may also be placed in somebody's path with no other purpose than to injure him seriously, or be hidden in somebody's house to bring on illness and insanity. What particularly concerns preachers is the way that a chitumwa is more or less regarded as having a life of its own. It is said, at least by preachers, to breathe and-very revealing of its intrinsically malicious nature!-to excrete occasionally a greenish substance.

According to Marwick (1965) no air of ambiguity need surround this type of amulet; being neutral, it is usually valued positively for the protection it offers its owner. Such amulets can belong to the realm of defensive sorcery, since they may function to warn their wearer, for instance, of an approaching sorcerer or witch. He noticed too that, in order to be effective, zitumwa are generally seen as requiring specific activating agents (zizimba, sing. chizimba) such as specific roots or pieces of snake skin. To be particularly potent requires the input of human material. Really strong zitumwa (zitumwa za mphamvu) therefore demand of their operator an act of the utmost immorality like committing incest or killing a near relative (Marwick, 1965: 70). Only in such cases has the boundary been crossed into the realm of illicit sorcery. To the young preachers, however, merely to possess a chitumwa is to be involved in the worst depths of witchcraft because all amulets require dealings with the despised asing' ang a (medicine men) and all amulets are considered to have been activated through a chizimba of human origin. In addition to having these horrifying ingredients, to young preachers chizimba implies-indeed, epitomises-the process of wilfully entering into anti-social pacts and making agreements with the sing'anga, an accomplice of the Devil, for the purpose of personal empowerment. In other words, in their view a person who desires to become kukhwima has always to obtain or have dealings with a chizimba. We therefore need to examine more closely what, in the eyes of the young preachers, is entailed in a chizimba.

The chizimba, both as material and as a process involving, first fabrica- 
tion and then rules of how to use it, consolidates the bond a person must have already established with devilish powers. In their view, if a person wishes to obtain a powerful chitumwa, he must first have consulted a sing'anga, who is always having to cross the boundary between the world of daylight and the nocturnal world of witchcraft in his search for a piece of dead body. Furthermore it is the client who will be given some mankhwala ('medicines') in order to kill the required near relative; only when the client has succeeded in the murder will the sing'anga enter the cemetery at night and, opening the grave where the corpse has been buried, take those parts of the body from which the activating agent will be made. Furthermore at the time of preparing the chitumwa strict regulations will be laid down to the user concerning the 'proper care' of the amulet. One of the most common stipulations in this context is that the chitumwa must never be left alone or separated from the body of its owner. According to the young preachers, a person is kept in bondage to the Devil by the simple fact that, should he fail to keep to these stipulations, the powers of the chitumwa will get out of control and the activating agent will turn its destructiveness upon the wearer. As really powerful zitumwa, through their chizimba, are considered to be able to force a person to fly and join in witches' night dances (kutamba), in the eyes of the young preachers anyone who wears such amulets can himself (or herself) be no better than a witch. It should come as no surprise that explicit demands that the audience should hand in all zitumwa are felt to be embarrassing and done at great cost, and are therefore obeyed reluctantly and often covertly. But to the young preachers the amulet and its chizimba belong to a wider set of immoral relations which they forcefully repudiate.

The ability to handle successfully the forces and the power obtained through a chitumwa and to make use of its powers successfully in economic, business, sexual and even political affairs is an intrinsic part of being considered to be kukwhima. Generally, the elderly are recognised as being kukwhima by the way in which they hold the high ground in all the major sectors of life. Such men and women have been able to establish, for instance, a flourishing business which provides them with economic standing and influence; they have authority in the home village among relatives and have too an influential position in one of the established Churches; they may even have power in and through the political system. In the eyes of the young preachers, in all these areas of life the elderly should be suspected of having used the help of zitumwa and their zizimba in order to gain such positions of respect. The power of the elderly has been attained only through malicious dealings in witchcraft; it has certainly not been received through malitime. In other words, the young preachers see themselves as being 'hardened' and 'ripened' through their link with superior heavenly powers, while the elderly in their day-to-day affairs are suspected of being kukwhima only because of pacts of a devilish nature.

Conventionally the village is seen as the major source of such evil powers. It is from the rural areas that devilish liaisons emanate and are carried from there into the urban environment. Apart from the powerful amulets brought in from the villages, according to the young preachers there come too the 'speaking calabashes' (nsupa) in which evil spirits are kept and penetrate the most powerful 'medicines' and the rituals of the sing'anga. In many stories, repeated over and over again, about occasions when they have visited their home villages the young preachers tell of sudden attacks upon them by witches at night, of owls making noises on the rooftop, of hands grabbing at their throat in an attempt to suffocate them while asleep. Every time, however, to have been Born Again is sufficient to ward off such witchcraft-related afflictions.

For the young preachers, power bestowed by evil therefore is strongly associated with the village and with the machinations of elderly relatives there. The village is a defiled area, witchcraft-ridden, the place where 'immoral' traditional customs, initiation and the like, still hold sway, since it is the place where ancestral veneration (known as nsembe or sadaka) is still of paramount importance. At the same time one may ask why young people, urban-born and bred and experiencing village life only at a distance, should have this kind of bitter, worried and resentful feeling about villages. Nonetheless such feelings are expressed quite emphatically, even to the extent that one young preacher openly said that he had come to 'hate' his father in his home village, because, he alleged, of his father's involvement in witchcraft.

The threat of being forced to take up residence in the home village looms large. Life in an urban area like Blantyre to a large extent is target-oriented in the sense that a person stays and settles in town for specific reasons of employment, education or medical treatment. Life in town is expensive. Prices of basic commodities are high, while the modal income level, as part of government policy, is kept low. There are no opportunities for any subsistence-level existence in town, since there is no room for gardens in the congested residential areas and, owing to residents' already low levels of income, paying for the upkeep of a dependent relative becomes problematic. 'Just visiting' (kungokhala) by dependents in town is scarcely supportable when there is no ready way to generate an extra income or to produce extra food for the household. Hence, whenever paid employment or education ceases to be a viable 'target', going back and living in the home village may prove to be the only alternative. At least in the village a person can make himself useful and contribute, while the costs of living are reduced to a minimum. Thus the simple need to survive may force a person to leave the city and may compel him to settle (as the young preachers see it) in a defiled environment ruled by an older generation suspected of evildoing.

What the rejection of zitumwa and their zizimba therefore means is that a rigid moral order is created whereby the door is shut both on the realm of worldly lusts and temptations (for which an amulet is a desirable asset) and on the spheres of gerontocratic control where the 'village' is seen as the prime source of the elderly's empowerment. In urban life, however, in one specific area-that of political control-the preachers are quite aware that careful negotiation, not rigid rejection, is the order of the day.

NEGOTIATION AND THE GERONTOCRATIC POLITY

Though expressing themselves less bluntly, yet through their messages and 
their actions leaving the audience in no doubt what they are referring to, the young preachers issue dire warnings about a second source of defilement that threatens the true believer almost as much as witchcraft. Involvement in politics is seen as a second important route for becoming kukhwima, for attaining the 'hardness' or 'ripeness' appropriate to that stage of life. Kukhwima (like witchcraft) in this context means that a person has proved capable of dealing with the somewhat secretive and potentially damaging force which politics have gradually become in post-independence Malawian society. Especially in Blantyre, party-political power has been able not only to challenge but to replace other forms of traditional and religious authority. In this section, then, we will focus on the implications and meaning this political power has for the activities of young preachers in the local residential areas of Blantyre.

Urban Blantyre can be summed up in one phrase: Christian territory. To a large extent the social, economic and political structures of contemporary Blantyre are still heavily influenced by a past rooted deep in missionary work. Blantyre was founded as a mission post by Scottish Presbyterians who, inspired by Dr Livingstone, decided that this particular spot in the Shire Highlands would be a convenient point from which to begin the work of spreading Christianity and commerce (Pachai, 1967). From 1873 onwards Blantyre (named after Livingstone's birthplace) grew rapidly. As it did not have its origins in a former African village with its own social and authority structure (Rangeley, 1954), Blantyre, practically from its very first day, was therefore a place run according to missionary and later colonial concepts. Gradually Blantyre swallowed neighbouring villages, with the result that in some parts of the urban area traditional authority and traditional social structure have managed to retain a certain significance up to the present. Today, in some areas of Blantyre, village headmen can be found who still lay claim to authority, mainly over the allocation of land to those wanting to settle within their area of jurisdiction.

For Blantyre as a whole the influence of the dominant Presbyterian, Roman Catholic and other Western established Churches is still paramount. The Churches not only brought into existence such large and important institutions as hospitals, schools, factories and printing presses, and laid the foundations for institutional cadres, boards and councils, but they still hold direct sway over the social fabric of everyday life. Great stress was laid on the development of private enterprise and industriousness, on the formation of nuclear households, on the acquisition of specific skills and educational qualifications and on the rejection of traditional customs and dances. Furthermore the creation of schooling and employment and the availability of medical treatment early on in the days of missionary endeavour triggered the settlement of a wide variety of people according to ethnic identity (Ross, 1975: 95).

Blantyre is now a multi-ethnic city harbouring a multitude of established and independent Churches, a city which above all has profited from a fast-growing trade and commercial sector. Blantyre's economic life is flourishing: the secondary and tertiary sectors show a steady growth of employment with a tendency to demand higher educational qualifications. At first glance, then, both the field of religion and the economy seem to breathe an atmosphere of freedom, of free enterprise, of free establishment of Churches, an open market for employment and education, and opportunities to reduce the influence of traditional authority and obligations to a minimum. But socio-political reality, especially after independence from British colonial rule in 1964, points in another direction. The new Malawi government sought to extend its supervision to cover all major sectors of society. The agricultural and industrial sectors of the economy came to be supervised through controlled marketing boards, government holdings and extensive legislation. In other areas of public and cultural life, too, such as the media, education, health care and the like, the post-independence government of Malawi gradually took over leadership and control (Williams, 1978: 227, 230). The Malawi Congress Party (MCP) became the sole governing party and, at the local level, its influence was felt through a system of locally elected party chairmen and through two related paramilitary party youth wings. Particularly in town the supervisory role of the party came to be clearly visible through the establishment of an intricate network of party chairmen.

At the grass roots, in the daily life of the Blantyre townships, it is the party chairman (rather than any form of traditional authority) who de facto controls public order, political dissidence or criticism. As an official of the Chipani (the party) the chairman settles conflicts, disputes and quarrels and even witchcraft offences. No meeting of any significance or magnitude may be organised without the chairman's prior consent nor can funerals or weddings be held in his local residential area without his first being notified. An important aspect of his work is to ensure the people of his area attend the compulsory party meetings and hear the public speeches of prominent party members and government officials. In short, the chairmen have a monopoly of the means of information within the townships.

In order to exert his authority the chairman has at his disposal one of the two youth organisations. Officially called the League of Malawi Youth (in local parlance it is Ayufi), these are tough youths-boys and girls-clothed in clearly recognisable uniforms of red shirts or blouses and green trousers or skirts. They are given extensive responsibilities (and liberties) in maintaining law and order in the local residential areas and perform specific tasks for the MCP. For example, they sell the compulsory party cards and stand at entrances to markets and at bus stops and other key public places in order to check that people are carrying their cards. Furthermore they are allowed to track down thieves, thugs and 'subversive elements' sought by the chairman or other authorities. They are also usually called upon to round people up for the compulsory party meetings, and this more often than not involves intimidation and ends in violence. The Youth League has come to be the tough right arm of the party and its chairmen.

Thus, since independence it has been a consistent policy of the Malawi government to involve specific youth organisations in its supervisory mode of administration-hence the MCP's slogan, 'Youth, the spearhead of progress'.

By about 1971-73 the progress of developing this extensive system of surveillance by the government and the party was complete, but there was one significant area which was not covered-and this is of importance for 
assessing the way the young preacher phenomenon arose. The one area of life which was left relatively free of party-political involvement was religion. Ufulu wa chipembedzo, freedom of worship, was (and is) given great emphasis by the life president, $\mathrm{Dr} \mathrm{H}$. K. Banda, as a matter of pride and attributed to the way law and order prevail in the country. Significantly, as soon as the government's supervisory structures were in place, there was a noticeable influx of (mostly right-wing) religious groups into Blantyre. This expanding field of religious activity was (and still is) left free of governmental interference so long as religion does not get mixed up with politics. At the time only Jehovah's Witnesses seem not to have accepted this message, when they started refusing en masse to buy the compulsory party cards any longer (Williams, 1978: 248; Short, 1974: 257; Hodges, 1976). The party and the government reacted by expelling the entire membership from the country. The youth wings were allowed to launch vigorous pogroms against the Jehovah's Witnesses which caused an international outcry.

By 1973 the pogroms had ended. In 1974 the first report is found of young preachers conducting open-air revival meetings in one of Blantyre's townships. ${ }^{5}$ Without suggesting a direct relationship between the two events it is nonetheless clear that the young preachers have learned from the Witnesses' experience never to touch upon political issues during thei preaching sessions. The dictum 'religion and politics do not mix' is turned into a rule of their own by Born Again preachers very aware that they, as religious practitioners, are allowed some freedom or (to introduce the concept we need here) some room for manoeuvre. The young preachers, and particularly the older cohort who acted as the 'pioneers' of the movement, have been able rather skilfully to exploit this freedom in the religious field by being constantly alert to any interference from politicians in their affairs. Ceaselessly the young preachers try to keep politics at bay, and ward it off using almost the same terms as they use when faced with the forces of evil. Yet since they are living in an urban environment where de facto authority, at the level of everyday life in the townships, is in the hands of party chairmen, the preachers need to negotiate with them so as to reach a modus vivendi.

In the past, the young preachers found themselves on occasions in conflict with local party chairmen and other officials, who were somewhat surprised to see young boys and girls conduct meetings for large audiences. On a few occasions in the late 1970 s and early 1980 s young preachers found themselves arrested by officials of the party or brought before party chairmen and made to explain their activities. This led preachers to adopt a range of tactics to ensure that the authorities are unperturbed and do not feel challenged. One tactic is to ask the party chairman of the area for explicit permission to conduct open-air revival meetings; another is to avoid any involvement whatsoever in political organisations. Other tactics are to stay away from compulsory party meetings, to select very carefully what topics to preach upon and even to take care with choosing what names to give churches, ministries and fellowships. As one informant stated:

none of the ministries carries the name of its founder, in order not to provoke the government. We had to think long and hard to find a suitable name for this ministry, but in the end I came up with the 'Redemption Voice Ministry'. In fact this was intended not to provoke the things which happened to Alice Lenshina in Zambia, who ran into difficulties with the government as well. [Interview with Mr H.D. Blantyre, 15 May 1989]

On the whole, however, the young preachers tend to see involvement in politics as defiling, something from which 'true men of God' refrain. Like witchcraft and immoral behaviour, such involvement impairs their precious bond with the heavenly powers. A person is considered to be an anagwa, a lapsed believer, from the very moment he or she becomes involved in party-political activity of any kind. 'Politics' and 'uniforms' are 'things of the earth' (zinthu za kunthaka) as opposed to things of heaven. As the young preacher L.M. would state: 'The uniform cannot revive you'. What the young preachers hold against the Ayufi (who are in fact their age-mates) is that these tough youths are 'bound up with the things of the world' and therefore 'unable to learn the things of God'. Merely by allowing themselves to be used as instruments in the hands of party officials the Ayufi have wilfully entered into an anti-social pact, the clearest indication of which is their use of intimidation and violence. It was evident that preachers had a profound fear of the harm that the political apparatus of local chairmen and youth wings could do to their struggle for purification and personal empowerment should politics ever intrude into the religious field. In short, politics posed a threat very similar to that posed by witchcraft: there could be no open discussion about it, there were few countermeasures available, and protection was usually hard to find.

Government's supervision of everyday life at the local level in the townships is defined by the young preachers, once again, in terms of the elderly exerting their malevolent power. As the majority of the party chairmen are indeed elderly people, and as they too are seen as having empowered themselves as kukwhima both by magical and political means (as well as having at their disposal a group of young toughs), they could be regarded as the 'new' gerontocracy. The young preachers therefore firmly reject both any involvement in witchcraft and any engagement in politics. They withdraw from relationships with the gerontocracies of both village and town, and seek to escape their influence. Hence such room for manoeuvre as the young preachers have created themselves is located in an area between two sources of defilement, two spheres of gerontocratic control. The final question to be tackled is what sort of room for manoeuvre this is, and why the young preachers seem not to have opted instead for setting up exclusive settlements of Born Again true believers in the manner most commonly found among puritan movements elsewhere.

\section{THE 'URBAN CONFUSION' MODEL}

It has been primarily the 'older' preachers, being among the better educated and economically more independent, who embraced the Born Again ideology as a way of creating in Blantyre some free religious 'space' in the form of a Born Again network that would allow them to protect as well as expand their room for manoeuvre. They had, so to speak, the tactical power as well as the initial advantage to generate the activities and organisations which 
form the Born Again network. The Born Again ideology proved highly effective as well as being sufficient to keep both defiling forces at bay; it also made it possible to establish that people might attain to being kukwhima through malilime only. It is scarcely surprising that very few middle-aged or older people can be found among either the Born Again preachers or their followers. The religious 'space' that these first young preachers created is today a still expanding field in which new young preachers can be found starting their own careers proclaiming the Born Again ideology with as much zeal as ever. In the last section we will turn to the question how this style of youthful, but careful, assertiveness stands in relation to the model of religion as an adaptive device in a situation of urban disruption.

In order to answer this question properly we have to explore first the reasons which, according to several authors on urban religious groupings, account for the formation of isolated pockets of 'true believers'. In several of the studies the explosive growth of urban independent Churches is correlated with the increased rate of urbanisation over the last decades, which in turn entailed a dramatic change in social relations brought about by capitalist and industrial labour relations (see for a review of the literature Kiernan, 1981). In general terms the Churches are seen by the majority of these authors as being able to provide adequate and apt means to allow the rural-to-urban migrant to adapt and adjust to the confusing, anarchic and fragmented reality of urban life (see, for instance, Kiernan, 1977: 32, 1981: 142; West, 1975: 202; Dillon-Malone, 1978: 125). Basically, the Churches provide a comforting rural-to-urban continuum in the way they handle their intrinsic social and authority structures, their references to a stock of religious symbols and rituals and their ways of coping with illness and misfortune. Comaroff adds to this, in her description of Zionist groups in the city of Mafeking, a strong emphasis in the recreation of symbols from the past in such a way that apartheid may be successfully resisted (1985: 194-9). One of the basic features which, especially in accounts of Zionist Churches, takes a key position in indicating the rural-urban continuum is the transformation of the role of nganga (traditional healer) into that of Zion prophet. Sundkler was one of the first to draw attention to the many similarities to be seen between the way 'heathen' diviners worked on illness, misfortune, involvement in witchcraft and sorcery and the way prophets exert their authority within rural and urban Zion bands. ${ }^{6}$ In fact for him the prophet-leader of the Zulu Zion healing Churches which started up in South Africa at the turn of the century is an isangoma diviner in disguise, even in the field of witch finding: No healing is complete until the prophet has found and removed from the patient's hut some horn or bottle supposed to contain ubuthakathi-poison' (Sundkler, 1961; 264). Prophet leaders of urban Zion bands are therefore seen as living embodiments of the process of rural-urban continuity as they stress above all the authority of seniority and the mores and values pertaining to a more or less traditional communal life. West shows that in Soweto prophets rearrange the cosmology in such a way that the ancestral spirits are given an intermediary position between man and the Holy Spirit from which they believe superior power can be derived. Many urban prophets in Soweto are in fact converted traditional diviners stripped of their tribal markings and thereby fit to enter a pluralistic and multi-ethnic scene (West, 1975: 183-5). The basic dividing line between the traditional diviner and the urban prophet is that the latter claims that his powers are superior and extend beyond the boundaries of a single ethnic or communal setting; and this facilitates, even in the most difficult urban environment, a reintegration of the afflicted person into a new, meaningful community. The prophet has the advantage of links with a close-knit community in which healing and purification may take place. As West aptly states:

Purification may be attractive for its links with tradition, but it is also attractive for its immediate, alleviating role in the urban situation; in other words this is another aspect of the independent churches which is a blend of the old and the new $[1975 ; 188]$

We suggest that this blend of old and new in the churches is an important factor in attracting members into their congregations because it facilitates adaptation to the urban environment by providing an important link between it and the environment from which they came [1975: 196]

Directly related to the rurat-urban continuum is the formation by these Churches of exclusionist communities which offer encapsulation and withdrawal from wider urban influences;

One of the foremost concerns of a Zionist band in Kwa Mashu (Durban RVD) is to protect itself against the township as an African community by drawing and maintaining boundaries setting off its membership from the rest of the population. [Kiernan, 1974: 82].

Apart from these Zulu Zion bands, in almost every one of the urban religious groupings we referred to earlier this quest for isolation has been noted. Quite explicitly Dillon-Malone even mentions that the tight-knit Masowe communities (see also Kileff and Kileff, 1979, on this point) offer a secure setting for the preservation and continuity of traditional styles of life and religious beliefs (Dillon-Malone, 1978: 129-30). The communities, as it were, form 'rural' enclaves amidst a sea of urban modernism which the (older) settler does not know how to cope with. Rural-to-urban continuity exists thanks to the successful establishment of an exclusionist settlement.

This exclusion and withdrawal indicate that the leadership have found the ways and the means to regenerate the social control which was formerly provided by rural kin groups. Traditional values are emphasised, while the leadership certainly has the means of disciplinary action (West, 1975: 198). Kiernan defines the control and restrictions on outward relationships, on the boundaries of the band within the urban township, as having a puritan quality as well and shows how in many respects the confirmed Zion member is supposed to exemplify his or her distance from the urban world. Meetings are seen as being held within the 'gates' and persons are appointed as 'gate-keepers' to patrol the 'threshold' of the meeting place (Kiernan, 1974: 83). Staves charged with spiritual power, purified water and specific garments are symbolically carried over the threshold, thereby taking on their purging power. Within the gates these garments, the use of purified water and staves are meant to ward off malevolent forces from the outside world, which guarantees the status of the wearer as being disengaged from the world outside. Newcomers and strangers within the band are viewed 
with suspicion and may cause a 'leak' in the exclusiveness of the grouping. From day to day moral injunctions are to be kept (no drinking, smoking and the like), and the Zionist is considered to avoid any deep involvement in urban working and leisure relations, which Kiernan refers to as the most common male world of working-travelling-drinking, and gambling sets and networks. In his work the Zionist is expected to opt for the kind of work that still leaves some autonomy of action and which leaves the possibility of social distance from others. It leads Kiernan to conclude that the urban Zionists are primarily engaged in erecting a barrier between themselves and fellow Africans so rigid that one begins to wonder how Zionism can survive this exclusiveness, since no 'fresh blood' from outside can enter easily to provide for natural growth and rejuvenation.

Kiernan concludes that the encapsulation of the Zion bands through their rigid puritan ideology functions to overcome the hardships of desperate poverty, of being 'at the bottom of the urban heap', of being deprived of the adequate material and non-material endowments which could alleviate their position in an artificial industrial environment, while at the same time the band functions as a welfare agency to which its members in need may turn for help (Kiernan, 1977: 40). The link between being poor and being puritan is indivisible, strengthened by deprivation, inequality and the loss of a meaningful, supportive local kin group.

Interestingly, the Churches offer within these exclusionist communities ample opportunities for leadership that are most attractive to the older rural-to-urban migrant (West, 1975: 199). As Wishlade showed with Malawian independents, there are strong parallels between the position and functioning of independent Church leaders and village headmen (Wishlade, 1965: 80). As most of the urban Churches have a high proportion of middle-aged people, and as the Churches have elaborate hierarchical structures with many positions of authority to be divided among their membership (see, for instance, West's chart of selected hierarchies, 1975: 70 ), many older men specifically find sufficient means and opportunities to regain something of their lost status. In fact seniority is the rule, and it is unusual for a man to become leader or to assume some authority under the age of fifty (West, 1975: 53-5; this process is also confirmed by Johnson 1977: 57-62, for the AME Church, and by Dillon-Malone, 1978: 105-7 for the Masowe Apostles). To conclude, as regards both age and inspiration, therefore, the urban Churches provide the means to retain some continuity (in organisation, authority structure and experience) with the rural background of most of their adherents.

If in this conclusion we now try to fit the Born Again young preachers into this urban confusion model (the young preachers being exclusively an urban phenomenon), we are likely to meet many difficulties. The main problem is that the young preachers do not appear to fit readily the profile of the typical urban independent Church member, who is likely to be a poor, older rural-to-urban migrant facing many difficulties in coping with the realities of urban life. For the most part the preachers are young, and they are certainly not poor-indeed, an important section of them have dealt with urban life quite well, since they manage to attain high-ranking positions and have developed into fully fledged religious entrepreneurs.
They seem to reflect achievement and ambition, which to the younger section of preachers act like a beacon for the sort of career they wish to pursue themselves. Furthermore, most of the time they are not to be viewed as rural-to-urban migrants, since many of them have been born and brought up in the city and have become estranged from their 'home-village' to a great extent.

In other respects, too, there is little which would allow us to believe that the young preachers form part of a rural-to-urban continuum. Their religious authority seems neither in form nor in content to be a transformation of any equivalent among traditional Malawian diviners, and, contrary to the practice of the Zion prophets, it does not reflect the operation, symbolic repertoire and inspirational sources of tribal sing'anga. In their healing practices the young preachers cannot be compared with diviners, since they do not diagnose the exact cause of an affliction, nor do they make use of medicines, concoctions or purified water in administering healing: they do not seek inspiration via the shades or other ancestral spirits, and so forth. They simply lay on hands, and no more. Certainly the young preachers, like the Zion prophets, claim to be able to tap into superior heavenly powers. This claim is fundamental to their view of a Manichaean world split between ultimate Good and ultimate Evil, in which all other types of spirits, medicines, concoctions and purifications are 'satan-ised' and categorised as belonging to the world of Evil. As was shown in their rejection of chitumwa and its chizimba this repudiation is rigid, leaving no middle ground for traditional healing and traditional empowering practices to re-enter.

This in turn leaves little opportunity for a rural-to-urban continuum to be grounded in an enclave, an exclusionist pocket where rural and traditional social structures, symbols, experiences and supportive kin groups may become re-created to suit the needs of the 'lost' migrant. Instead ties with the home villages are boldly minimised by the young preachers, and generally village life is treated with suspicion and contempt. By contrast-and quite contrary to the way Zion bands are said to function by Kiernanwithin their urban environment the young preachers deliberately open themselves to the wider public, and with great zest seek every opportunity to attract an urban audience to their meetings; they have no hesitation in appealing to those who have yet to be Born Again to take the step. During their meetings we find no 'gatekeepers' patrolling the symbolically charged 'threshold' of the meeting place, nor do we find specific objects such as staves or bowls of water or white clay being employed to purify the inner circle of the meeting place and its attenders and to ward off malevolent external powers.

Nonetheless we would still call the Born Again movement a protective environment taking explicit care not to label it a community as such. This protective environment, however, does not function to relieve harsh socioeconomic deprivation, inequality and confusion, nor is it caused by such; instead it acts as an area of free religious 'space' in which the young preachers have actively found an opportunity to create a niche in the social fabric of everyday life. The Born Again network, therefore, should not be viewed as a result of deprivation and disruption but rather as growing out 
of a deepening antagonism towards, and resentment at, the stern supervision characteristic of Malawian urban life. It is the form and content of the closely supervised character of social life, reflecting a transformation of the closely supervised chac traditional gerontocratic relations to moung preachers to seek restlessly for an area free from such controls in society.

What the young preachers have in common, therefore, with Zionist puritanism is their rejection of evil ways, immoral behaviour and any puritanism is their rejection of e like. But where they differ strongly is in their ability to cope skilfully with, even to prosper in, urban life, in their not being victimised by its socio-economic relations, and in being able to not being victimised by create space for masic inadequacy of the 'urban confusion' and coercion. The fact that it provides no analytical insight into the functionmodel lies in the fact that it provides no analytical insight into the functioning of those und deprived state of the older migrant. As such, the Born Again confused and depriver winners, and hence the mutual support offered, whether material or non-material, is very limited. The 'urban confusion' model fails to provide a deeper understanding of why such a movement flourishes in an urban setting in the way it does today.

\section{NOTES}

1 The present population stands at over 400,000 persons (Malawi Population and Housing Census, 1987, Preliminary Report)

(1989) on the Mazimu groups of southern Tanzania, Kileff , for instance, Thoden Van Velal (1978) on the Masowe Apostles throughout the Kileff and Kileff (1979) and Dillon-Malone (1978) on the Masowe Apostles throughout the region, Jules-Rosette (1975) on the Maranke Apostes, Kieman (1974, 1977, 1982), Comar

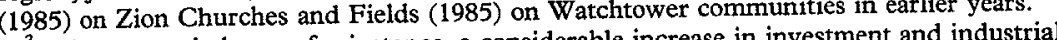
3 The two periods saw, for instance, a considerable increase in investment and industrial and business settlement in Blantyre. By 1984 the city was the site of two-thirds of the total industrial employment in the entire country (see National Physical Development Plan 3,
Background Study Report, 1987: 76-80).

${ }^{4}$ Schoffeleers personally witnessed this influx in the southernmost part of Malawi and has reported on these develpments in the rural area of Nsanje (Schoffeleers, 1985). I learned through a small survey at the Registrar's Office of Blantyre that over half the nearly 100 different denominations and Church bodies in Blantyre were established and registered during this period.

'Teenage preachers leave crowds agape', Malawi Nezws, Saturday, 1 June 1974.

6 This line of thinking about continuity, and how old concepts and structures are transformed into urbanised counterparts, is an integral part of Sundkler's paradigm of 'new wine in old wineskins'. Basically his argument is that Zulu Zion presents a form of Christanity containing old Zulu concepts in disguise. Basic Zulu notions of spirit possession and afflictions, of the 'breath of life' (umoya), of concepts and methods of healing by isangoma and of ancestral veneration are transformed into Zionist notions of the Holy Spirit, of the functioning of prophets and their healing powers and in the Zionist use of paraphernalia, colours, purifi-
cation rites and so forth.

The following incident led Sundkler to conclude that the age-old isangoma diviner, with all his/her powers and paraphernalia, could be suddenly transformed into the important role tha prophets take on and display in Zionist groupings. By coincidence, one morning an isangoma diviner and healer left her kraal with her group of adepts to go down to a small stream. Ther they found, coming down from the other side, a group of Zionists with their prophet leader too. While chanting songs to the ancestral spirits the sater, and added certain medicines to it.
Every member of the group was offered a drink of this concoction, whereupon they started to vomit. To conclude the ceremony their bodies and faces were smeared with white clay. Thereupon the group of Zionists, mocking the isangoma group as they left, also entered the water, singing their songs to the Holy Spirit, blessing the water in order to remove all 'impurity'and finally drinking the water, which was said to take away all illness for the sick or afflicted person. After drinking the water the afflicted persons among the Zionist group started to vomit too and, while a session of speaking in tongues was held, their faces and shoulders roup, as they left the Zionists walked along whilst dancing and the stream. Like the isangoma 239.) To Sundkler the similarities, as well as the proceses of tranformation, we

\section{REFERENCES}

Comaroff, J. 1985. Body of Power, Spirit of Resistance: the culture and history of a South African people. Chicago: University of Chicago Press.

Dijk, R. A. van. 1990a. 'Mini-Swaggarts and Grahams; the young preachers of Malawi', Fournal of Social Science, University of Malawi, forthcoming.

- 1990b. 'Impurity and Imbroglio: young preachers and the attack on moral disorder in urban Malawi.' Paper presented at the EIDOS conference 'Giving Disorder its Due', 20-3 June, Free University, Amsterdam.

Dillon-Malone, C. M. 1978. The Korsten Basketmakers: a study of the Masowe Apostles, an indigenous African religious movement. Manchester: Manchester University Press.

Fields, K. E. 1985. Revival and Rebellion in Colonial Central Africa. Princeton, N.J.: Princeton University Press.

Hodges, T. 1976. Jehovah's Witnesses in Central Africa. Report 29, London: Minority Rights Group.

Johnson, W. R. 1977. Worship and Freedom: a black American Church in Zambia. London: International African Institute.

Jules-Rosette, B. 1975. African Apostles: ritual and conversion in the Church of fohn Maranke. London: Cornell University Press.

Kiernan, J. P. 1974. 'Where Zionists draw the line: a study of religious exclusiveness in an African township', African Studies 33 (2), 79-90.

1976. 'Prophet and preacher: an essential partnership in the work of Zion', Man, 11 (3), 356-66.

- 1977. 'Poor and puritan: an attempt to view Zionism as a collective response to urban poverty', African Studies 36 (1), 31-41.

- 1981. 'African religious research: themes and trends in the study of black religion in southern Africa', fournal of Religion in Africa 12 (2), 136-47.

1982. 'Authority and enthusiasm: the organisation of religious experience in Zulu Zionist Churches', In J. Davis (ed.), Religious Organisation and Religious Experience. ASA Monograph 21, New York: Academic Press.

Kileff, C., and Kileff, M. 1979. 'The Masowe Vapostori of Seki', in B. Jules-Rosette (ed.), The New Religions of Africa. Norwood, N.J.: Ablex.

Marwick, M. G. 1965. Sorcery in its Social Setting: a study of the Northern Rhodesian Cewa. Manchester: Manchester University Press.

Ojo, M. A. 1988. 'The contextual significance of the charismatic movements in independent Nigeria', Africa 58 (2), 175-192.

Pachai, B. 1967. 'In the wake of Livingstone and the British administration: some considerations of commerce and Christianity in Malawi', The Society of Malazir fournal 20 (2), 40-70.

Rangeley, W. H. J. 1954. 'Early Blantyre', The Society of Malawi fournal (The Nyasaland Journal) 7 (1), 36-45.

Ross, A.C. 1975. 'The Blantyre Mission and the problems of land and labour, 
1891-1915', in R. J. MacDonald (ed.), From Nyasaland to Malawi: studies in colonial his

(the religious polariSchoffeleers, J. M. 1985. Pentecostalism Mawi. Amsterdam: Free University Press. zation of a rural district in southern Malawe.

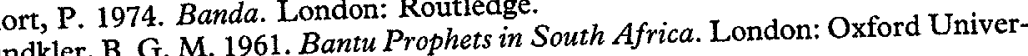
sity Press, for the International African Institute.

sity Prus,

Thoden van Velzen, $H$. U. E. 1989. Mazloquium on African Religion and Ritual, 18-21 April 1989

18-21 April 1989 iden van Velzen, H. U. E. Beek (ed.) Ouest for Purity. Berlin: Mouton.

ideology', in W. E. A. van Beek (ed.) Quest for Pun Zion to the wilderness in Werbner, R. P. 1985. 'The argument of images. M. J. Schoffeleers (eds.), TheoreAfrican Churches', in W. van Binsbergen and M. J. Schoffele

tical Explorations in African Religion. London: Routledge.

West, M. 1975. Bishops and Prophets in a Black City: African independent churches in Soweto, Fohannesburg. Cape Town: David Philip. Williams, T. D. versity Press.

Wishlade, R. L. 1965. Sectarianism in Southern Nyasaland. London: Oxford University Press, for the International African Institute.

ACKNOWLEDGEMENTS

The research in Blantyre, Malawi, on which this article is based was made possible through The research in Blant the financial support of for which I am greatly indebted. An earlier version was presented at the the Tropics (OTRO), England, 20-3 April 1991 seventh Satterthwaite Colloquium on African Reug for the lively debate on the draft's conten I am graful to

\section{Abstract}

Dopulation of over 400,000 , there are some In Blantyre, constitute the Born Again movement. The organisations include 'ministries' and 'fellowships as well as 'churches'. The movement started c.1974. What is significant is that all the leader as werl as 'chengers; even today the second 'generation' of preachers are teenagers or in the early twenties. One theme dominates their message: vehement opposition to involvement in practices of a largely secretive or malevolent nature, witchcraft and politics' in particul. The practio preachers assume these forces to be the basis of the power that elders wield in the villages or in urban townships. Yet in Blantyre, where political survellance over eve is very marked, they have to be wary of challenging this older, powerful generation if they are to preserve the 'intellectual space' that religion offers them. The article ends by arguing that the theories which are used to explain urban Zionist Churches elsewhere in south the hot a

\section{Résumé}

C'est dans la zone urine plus importante de Malawi, Blantyre, ville de 400,000 habitants, que trente à quarante jeunes prêcheurs environ dirigent une quinzaine d'organisations constituant le mouvement 'Regénération' ('Born Again'). Les organisations comprennent aussi bien les 'saints ministères' et les 'confréries' que les 'églises'. Le mouvement a commence vers 1974. Il est significatif que tous les dirigeants étaient à l'époque des adolescents; encore aujourd'hui, la deuxième 'géneration' de prêcheurs comprend des adolecents ou dèn jeune d'une vingraine d'années. Leur message est dominé par un même thème: ils mènent une opposition véhémente contre les actions mêlées à des pratiques d'un caractère pour le moins mystérieux ou même malveillant, particulièrement la sorcellerie et la politique. Les jeunes prêcheurs présument que ces forces sont à la base du pouvoir exercé par les plus anciens dans les villages ou les communes urbaines. Pourtant, a Blantyre, ou la survellance politique sur la vie quotidienne est très forte, il leur faut rester très prudents en défiant la puissante génération precédente, s'ils veulent conserver 'l'espace intellectuel' qu'ils trouvent dans la religion. Enfin, dans sa conclusion, l'article soutient que les théories utilisées pour expliquer l'installation d'Eglises Sionistes en zones urbaines dans d'autres regions du sud de l'Afrique ne s'appliquent pas à l'analyse du mouvement 'Regénération', un mouvement dirigé avec succès par de jeunes citadins. 